\title{
Membangun Mekanisme Pembuatan Kebijakan Negara yang Partisipatif
}

\author{
Muntoha
}

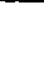

Abstract

It is common that in Indonesia, the economic considerations, stability and security often overcome considerations on society aspiration and their right as citizen. Otherwise people would respond warmly the changes made if they are invited to take a part in planning to create the changes. The process must be taken when it starts to design, reconstruct, implement and evaluate them.
\end{abstract}

\section{Pendahuluan}

Maraknya demontrasi di Indonesia yang dilakukan oleh para warga negara terutama para mahasiswa akhir-akhir ini, konon disebabkan karena kebijakan pemerintah yang tidak memenuhi aspirasi warga masyarakat. Di saat-saat daya beli warga masyarakat sangat menurun drastis, pemerintah mengeluarkan kebijakan yang menaikkan harga tiga sektor kebutuhan hidup warga masyarakat, yaitu harga bahan bakar minyak (BBM), tarif dasar listrik (TDL), dan tarif telepon. Sebagai akibatnya meletuslah aksi-aksi demo yang terjadi di sebagian wilayah nusantara, untuk menolak kebijakan pemerintah tersebut karena berdasarkan pengalaman empirik, dengan naiknya harga di tiga sektor tersebut akan berdampak pada kenaikan harga-harga di berbagai sektor kebutuhan hidup yang lain.

Dari berbagai aksi demo itu, kemudian direspon oleh pemerintah dengan merevisi kebijakannya itu untuk menunda kenaikan harga/ tarif ketiga sektor kebutuhan hidup warga masyarakat itu dan apa yang menjadi kebijakan pemerintah itu merupakan kebijakan yang aspiratif. Persoalannya adalah bagaimana membangun kebijakan negara yang aspiratif itu. Bukan rahasia lagi bahwa di negara Indonesia ini pertimbangan-pertimbangan ekonomis, stabilitas, dan security sering mengalahkan pertimbangan-pertimbangan mengenai aspirasi masyarakat dan hak asasi mereka sebagai warga negara. ${ }^{1}$ Kenyataannya, pembangunan politik dalam banyak hal telah disubordinasi oleh pembangunan ekonomi maupun kebijakan-kebijakan pragmatis pejabat tertentu. Sesungguhnya sudah saatnya untuk lebih memperhatikan kehendak rakyat yang sebenarnya, sekaligus untuk mendidik mereka

'Wahyudi Kumartono, Etika Administrasi Negara, Cetakan ke-1, (Jakarta: Rajawali Press, 1992), hlm. 111. 
yang terlibat dalam gerak pembangunan dengan sepenuh hati. Rakyat sudah semakin pintar dan tidak mudah lagi untuk dijejali dengan janij-janji kosong atau dipaksa untuk ikut serta dalam program-program yang bertentangan dengan cita-cita mereka. ${ }^{2}$

Dengan demikian, pentingnya partisipasi warga negara ini bukannya tanpa landasan. Apalagi di era reformasi ini telah terjadi perubahan sosial, politik, ekonomi, dan lingkup kenegaraan yang makin kompleks. Oleh karena itu, suatu keniscayaan untuk mengupayakan pembaruan tata cara penyelenggaraan pemerintahan agar sesuai dengan tuntutan zaman.

Isu reformasi administrasi negara pada perspektif masyarakat modern, umumnya dikaitkan dengan peluang untuk partisipasi. Bila pemerintahan dipegang oleh satu kelas sosial - apalagi ia pengejawantahan dari lapisan elite - maka produk kenegaraan tak pelak menjadi cenderung menguntungkan strata sosial yang elite itu. Kelas elite itu dimanifestasikan oleh politisi partisan, kerabat, korp, anak cucu, cronies, dan sebagainya. Bila demikian keadaannya, maka konduk kenegaraan lalu tampäk seperti penyelenggaraan sebuah urusan bisnis pribadi atau keluarga saja. Oleh karena itu, segala gagasan $k e$ arah pembaruan administrasi negara haruslah diarahkan agar sistem tata usaha negara itu kondusif bagi terciptanya iklim persamaan peluang bagi semua, mengurangi kebijaksanaan sepihak (arbitrainess) dan mencegah profiteering. Kepekaan instrumeninstrumen tradisional, guna melancarkan pembaruan administrasi seperti pemisahan urusan kantor, urusan pribadi dan urusan rumah tangga, penugasan berdasarkan kemampuan dan kecakapan (merit), jabatan diberikan atas dasar kontrak, lugas, dan lainlain, perlu dilihat dalam perspektif persamaan peluang bagi semua itu. ${ }^{3}$

\section{Urgensi Partisipasi Masyarakat}

Istilah partisipasi lażimnya dikaitkan dengan pembangunan. Dalam partisipasi ini sasaran utamanya adalah timbulnya keiikutsertaan aktif dari segala potensi lokal mulai dari perencanaan, pengambilan keputusan, dan pelaksanaan program-program pembangunan. Istilah ini tambah penting artinya, terutama di saat-saat redefining hakekat pembangunan mulai dilakukan. ${ }^{4}$

Isu partisipasi dalam proses pembangunan mulai populer sebenarnya pertama kali muncul dalam masyarakat negara-negara yang sudah lebih maju. Partisipasi muncul bersamaan dan bergandengan dengan pertumbuhan pendidikan, tumbuhnya institusi demokrasi, dan menyebarnya komunikasi. Kalimat-kalimat pembuka untuk menunjukkan betapa pentingnya studi dimensi politik terhadap proses partisipasi dalam negaranegara berkembang dapat dibaca misalnya:5

Broadening political participation is a hallmark of political modernization (Hunting-

\footnotetext{
2lbid., hlm. 112.

${ }^{3}$ Soetjipto Wirosardjono, Dialog Dengan Kekuasaan, Cetakan ke-1, (Bandung: Mizan, 1995), hlm. 137.

'Miftah Thoha, Beberapa Aspek Kebijakan Birokrasi, Cetakan ke-1, Yogyakarta: PT. Media Widya Mandala, 1991), hlm. 16.

s.bid., hlm. 16- 17 .
} 
ton dan Nelson, 1976)

Daniel Lerner, pada tahun 1958 telah mengatakan: Traditional society is non-participant ....Modern society is participant.

It is well established fact that in developed countries more people become involved in decision-making through citizen action groups and many other ways than is the case in countries which are less developed (Mathur dan Palla, 1983)

On the other hand, government in tradjtional societies tends to remain the concern of a small elite group (Mair, 1962)

It is a pretense ti think that the crisis that the third world is facing can be overcome and that the reshaping of its societies and the development of its rural areas can be undertaken without the participation of the people, particularly the large numbers who are poor (Wignaraja, 1984)

There is a growing consensus that people everywhere have a basic human right to take part in decisions that affect their lives. Consequently, participation in third world countries is being promoted by the United Nation agencies and the government themselves (United Nation, 1975)

China, Tanzania and Guyana are among the developing countries where participation has proceded quite far (Wertheim dan Stiefel, 1982)

The experience suggest-and encourages the hope - that participation is possible even in societies that are not yet part of the developed world. Following the success of these efforts, participation in some form or the other is being included as an impor- tant element in development strategies of most third world countries (Oakley dan Marsden, 1984)

Lothar Gundling mengemukakan 4 (empat) dasar bagi pentingnya partisipasi masyarakat, sebagai berikut : ${ }^{6}$

(1) Memberi Informasi Kepada Pemerintah. Partisipasi masyarakat terutama akan dapat menambah perbendaharaan pengetahuan mengenai sesuatu aspek tertentu yang diperoleh dari pengetahuan khusus masyarakat itu sendiri maupun dari para ahli yang dimintai pendapat oleh masyarakat. Partisipasi masyarakat sangat diperlukan untuk memberi masukan kepada pemerintah tentang masalah yang dapat ditimbulkan oleh sesuatu rencana tindakan pemerintah dengan berbagai konsekuensinya. Dengan demikian, pemerintah akan dapat mengetahui adanya berbagai kepentingan yang dapat terkena tindakan tersebut yang perlu diperhatikan. Pengetahuan tambahan dan pemahaman akan masalah-masalah yang mungkin timbul yang diperoleh sebagai masukan partisipasi masyarakat bagi proses pengambilan keputusan pemerintah akan dapat meningkatkan kualitas keputusan tersebut.

(2) Meningkatkan Kesediaan Masyarakat Untuk Menerima Keputusan. Seorang warga masayarakat yang telah memperoleh kesempatan untuk berpartisipasi dalam proses pengambilan keputusan dan tidak dihadapkan pada suatu fait accompli akan cenderung untuk memperlihatkan

${ }^{6}$ Lothar Gundling, dalam Zairin Harahap, Diktat Mata Kuliah Hukum Administrasi Lanjut(Yogyakarta: FH. Ull, 2001), hlm. $69-72$. 
kesediaan yang lebih besar guna menerima dan menyesuaikan diri dengan keputusan tersebut. Pada pihak lain, dan ini adalah lebih penting, partisipasi masyarakat dalam proses pengambilan keputusan akan dapat banyak mengurangi kemungkinan timbulnya pertentangan asal partisipasi tersebut dilaksanakan pada saatyang tepat. Akan tetapi, perlu dipahami bahwa suatu keputusan tidak pernah akan memuaskan semua kepentingan, semua golongan atau semua warga masyarakat, namun kesediaan masyarakat untuk menerima keputusan pemerintah akan dapat ditingkatkan.

(3) Membantu Perlindungan Hukum. Apabila sebuah keputusan akhir diambil dengan memperhatikan keberatan-keberatan yang diajukan oleh masyarakat selama proses pengambilan keputusan berlangsung, maka dalam banyak hal tidak akan ada keperluan untuk mengajukan perkara ke pengadilan. Apabila sebuah perkara diajukan ke pengadilan, maka lazimnya perkara tersebut memusatkan diri pada suatu kegiatan tertentu. Dengan demikian, tidak dibuka kesempatan untuk menyarankan dan mempertimbangkan alternatif kegiatan lainnya. Sebaliknya, di dalam proses pengambilan keputusan, alternatifalternatif dapat dan memang dibicarakan, setidak-tidaknya sampai pada suatu tingkatan tertentu. Selain itu, ada beberapa bentuk tindakan administratif misalnya pemberian izin untuk kegiatan-kegiatan yang berhubungan dengan bahan pencemar (pollutant), dimana undang-undang dapat menangguhkan aksi perdata dengan ketentuan dikaitkan pada tenggang waktu tertentu. Apabila sebuah keputusan dapat mempunyai konsekuensi begitu jauh, maka sangatlah diharapkan bahwa setiap orang yang akan terkena akibat keputusan itu perlu dibertitahukan dan diberi kesempatan untuk mengajukan keberatan-keberatannya sebelum keputusan itu diambil.

(4) Mendemokratisasikan Pengambilan Keputusan. Dalam hubungan dengan partisipasi masyarakat ini ada pendapat yang menyatakan bahwa dalam pemerintahan dengan sistem perwakilan, maka hak untuk melaksanakan kekuasaan ada pada wakil-wakil rakyat yang dipilih oleh rakyat. Dengan demikian, tidak ada keharusan adanya bentuk-bentuk dari partisipasi masyarakat karena wakil-wakil rakyat itu bertindak untuk kepentingan rakyat. Dikemukakan pula argumentasi bahwa dalam sistem perwakilan, partisipasi masyarakat dalam proses pengambilan keputusan administratif akan menimbulkan masalah keabsahan demokratis, karena warga masyarakat, kelompok atau organisasi yang berpartisipasi dalam proses pengambilan keputusan tidaklah dipilih atau diangkat secara demokratis.

Terhadap kritik-kritik tersebut di atas, Gundling mengemukakan pendapatnya, yaitu: (1) bahwa demokrasi dengan sistem perwakilan adalah salah satu bentuk demokrasi, bukan satu-satunya; (2) bahwa sistem perwakilan tidak menutup bentuk-bentuk demokrasi langsung dan (3) bahwa bukanlah warga masayarakat, sekelompok warga masyarakat, atau organisasi yang sesungguhnya mengambil keputusan, mereka hanya berpartisipasi dalam tahap-tahap persiapan pengambilan keputusan.

Oleh karena itu, diperlukan penegakan partisipasi dalam sebuah konduk kenegaraan 
berdasarkan asas-asas birokrasi yang letaknya berada pada demokratisasi birokrasi. Menurut Soetjipto Wirosardjono, ${ }^{7}$ di masyarakat dalam kenyataannya ada berbagai golongan dan kepentingan. Mereka itu berhimpun mengorganisasikan diri dalam bentuk tradisional maupun modern. Lahirnya berbagai golongan dan kepentingan ini, umumnya bersamaan dengan meluasnya jaringan dan fungsi pemerintahan. Karena keduanya merupakan manifestasi dari respon terhadap berkembangnya kompleksitas tantangan yang dihadapi masyarakat dan pemerintah. Golongan dan kepentingan yang ada di masyarakat itu hakikatnya hadir dan merasa saling membutuhkan dengan fungsi-fungsi kenegaraan baik eksekutif maupun legislatif. Di satu pihak golongan-golongan yang ada di masyarakat itu memerlukan agar kepentingannya tersalurkan dan dipertimbangkan dalam pengambilan' keputusan dan konduk kenegaraan. Di pihak lain, negara - eksekutif maupun legislatif-perlu untuk memperoleh dan memperkaya informasi tangan pertama untuk dapat menjalankan fungsinya dengan seksama.

Format ideal dari demokratisasi-birokrasi ialah dilahirkannya kebijaksanaan yang beragam (pluralistic polity) dan responsif terhadap kekuasaan tiap problematik yang dihadapi. Birokrasi yang demokratis ialah birokrasi yang sudah mampu melenturkan kekakuan wajah rules dan regulations. Caranya, dengan makin mendesentralisasikan fungsi pengambilan keputusan baik secara vertikal maupun horizontal; termasuk desentralisasi perumusan kebijaksanaan pada berbagai tingkat, bahkan di luar batas birokrasi pemerintahan an sich; seperti pada panitia; task force. Di sisi lain, porsi yang masih perlu dipertahankan pada tangan pemerintah pusat - dan pusat pengambil keputusan ialah pokok-pokok persoalan yang menyangkut kebijaksanaan umum, garis-garis besar arahan dan kebijaksanaan yang bercorak global. Bahkan dalam sebuah birokrasi yang dewasa, proses pendemokrasiannya, kehadiran, dan partisipasi golongan dan kelompok kepentingan itu menjadi sangat dibutuhkan dan tak terelakkan, sebagai forum konsultasi, kerjasama bahkan legitimasi atas klaim negara yang tegaknya menggunakan premis kedaulatan. rakyat. $^{8}$.

\section{Mekanisme Pengambilan Keputusan}

- Mekanisme pengambilan keputusan dalam kaitannya dengan partisipasi masyarakat, berarti berbicara tentang partisipasi warga negara secara langsung di lingkungan pemerintahan. Oleh karena itu, sebelum sampaj pada fokus pembicaraan ini, perlu dibicarakan terlebih dahulu corak partisipasi warga negara. Secara umum corak partisipasi warga negara dapat dibedakan menjadi 4 (empat) macam: ${ }^{9}$

(1) Partisipasi dalam pemilihan (electoral participation). Ini merupakan corak patisipasi yang paling mudah dilihatkarena biasanya bersifat rasional. Aktivitas partisipasi massa dalam hal ini ditunjukkan untuk memilih wakil-wakil rakyat, mengangkat pemimpin, atau menerapkan ideologi

${ }^{7}$ Soefjipto Wirosardjono, op. cit., hlm. 137-138.

${ }^{8}$ Soetjipto Wirosardjono, Ibid., h/m. 138.

sWahyudi Kumartono, op. cit., hlm. 112-114. 
pembangunan tertentu. Oleh sebab itu aktivitas yang dilakukan antara lain kegiatan-kegiatan dalam partai, kampanye, mengisi kota suara, propaganda, atau menyumbangkan uang pribadi untuk kegiatan aksi tertentu. Di samping itu partisipasi dapat mengambil bentuk keikutsertaan warga negara dalam voting melalui koran, selebaran atau media massa lainnya:

(2) Partisipasi Kelompok (Group Participation), warga negara'bergabung dalam kelompokkelompok tertentu untuk menyuarakan aspirasi mereka. Kelompok-kelompok itu mungkin terdiri dari orang-orang yang bekerjasama ingin memerangi kemiskinan, mengadukan penyelewengan administratif kepada lembaga-lembaga kerakyatan, atau sekedar membela kepentingankepentingan. sekelompok individu yang sama. Jika di antara para pejabat dan kelompok-kelompok partisipan ini dapat terbina saling pengertian, kelompok ini dapat dimanfaatkan sebagai sarana penengah (intermediary medium) antara pejabat dan warga negara. la sekaligus bisa berfungsi sébagai saluran untuk mengkomunikasikan kepentingan warga. negara dengan pejabat-pejabat yang. berkompeten.

(3) Kontak antara warga negara dan pemerintah (citizen-government contacting), proses komunikasi dapat terjalin antara warga negara dengan pemerintahnya dengan cara menulis surat, menelpon, atau pertemuan secara pribadi. Untuk mengetahui kadar partisipasi warga negara, aparatur pemerintah mungkin ingin mengadakan survei mengenai opini publik atas kebijakan tertentu. Di beberapa negara terdapat saluran partisipasi masyarakat yang disebut ombudsman (di Indonesia sekarang lembaga tersebut. sudah ada). Pranata ini merupakan wadah dari setiap pendapat dan keluhan masyarakat atas kebijkan dabn layanan yang dilaksanakan oleh pemerintah.

(4) Partisipasi warga negara seçara langsung di lingkungan pemerintahan. Partisipasi seperti ini mensyaratkan keterlibatan langsung seorang warga negara di dalam pembuatan kebijakan pemerintah. Misalnya saja jika terdapat seorang tokoh masyarakat yang didudukkan sebagai wakil rakyat di lembaga-lembaga pembuat kebijakan. Cara yang lain ialah dengan menggaji client dari suatu program untuk menjadi pelaksana program itu sendiri.

Dalam kaitannya dengan mekanisme pengambilan keputusan, Prajudi Atmosudirdjo mendefinisikan keputusan sebagai suatu pengakhiran atau pemutusan dari suatu - proses pemikiran untuk menjawab suatu pertanyaan, khusunya suatu masalah atau problema. ${ }^{10}$ Menurutnya, secara teoritis proses pengambilan keputusan itu dibahas melalui tahapan pentelaahan terhadap leadership yang harus dijalankan, menelaah masalah yang dihadapi (identifikasi dan spesifikasi dari problema ini harus dilakukan secermatcermatnya), dan menelaah situasi dan kondisi keberadaan masalah yang terjadi, diteruskan

${ }^{10}$ Prajudi Atmosudirdjo, Beberapa Pandangan Umum Tentang Pengambilan Keputusan (Jakarta: Tanpa Penerbit, 1976), hlm. 36. 
dengan menelaah keputusan yang. harus diambil. Setelah keputusan diambil, maka keputusan tersebut akan diperintahkan untuk dilaksanakan, disertai dengan telaahan lanjutan dan akibat dari pelaksanaan keputusan tersebut."

Dalam hal ini, Beckky menyebutkan ada beberapa cara bagaimana keputusan itu dibuat. Beberapa cara itu antara lain sebagai berikut: ${ }^{12}$

(1) Keputusan Diambil Berdasarkan Otoritas, Tanpa Disertai Diskusi Kelompok.

Cara ini dilakukan oleh pemimpin tanpa didahului musyawarah dengan anggota kelompok. Cara ini sering dilakukan dan selalu terjadi dalam setiap organisasi. Cara semacam ini merupakan cara yang efisien dilihat dari segi waktu yang singkat, akan tetapi tidak efisien dilihat dari segi keterlibatan kelompok. Dengan cara ini seberapa jauh keputusan itu bisa dilaksanakan dengan baik masih merupakan keraguan yang besar sekali.

(2) Keputusan yang Dilakukan oleh Ahli. Keputusan kelompok dapat dilakukan dengan menyerahkan kepada anggota kelompok yang àhli di bidangnya. Prosedurnya dapat dimulai dengan memilih para ahlinya, dan membiarkan mereka mempertimbangkan isu-isu tertentu, dan kemudianmereka ini memberitahukan kepada kelompok tentang keputusan apa saja yang telah diambilnya. Persoalan yang muncul dengan cara ini adalah banyak orang yang tidak setuju dengan pendekatan yang dipergunakan, maka akan timbul kesulitan bagi mereka untuk mengenal siapakah yang paling ahli diantara mereka. Popularitas individu dan jumlah kekuasaan yang ada pada seseorang acapkali mempengaruhi pemilihan siapakah yang paling ahli tersebut.

(3) Keputusan Dengan Cara Mengambif Pendapat Rata-Rata. Cara inj dilakukan dengan memberikan serangkaian pertanyaan secara terpisah pada setiap anggota kelompok, menanyakan pendapatnya, dan menyimpulkan pendapat secara rata-rata. Dalam cara ini para anggota kelompok dimintai pendapat secara merata. Ini merupakan keuntungannya. Ketidak-untungan cara ini, antaranya pendapat dari anggota yang kurang cakap dapat menghapus pendapat dari anggota yang cakap, cara ini masih tetap mencerminkan keterlibatan yang sedikit dari anggota kelompok.

(4) Keputusan yang Diambil oleh yang Berwenang Setelah Diskusi Kelompok. Banyak kelompok yang mempunyai struktur kewenangan yang menunjukkan secara jelas bahwa suatu keputusan itu dibuat oleh pemimpin. Fungsi kelompok dalam cara seperti ini mendiskusikan ideide yang ada, sedangkan keputusan terakhir ada pada pimpinan.

(5) Keputusan yang Diambil oleh Minoritas. Minoritas di sini ialah dua atau tiga anggota yang mewakili kurang dari separuh anggota kelompok. Mereka ini

\footnotetext{
"Prajudi Atmosudircjo, Ibid., hlm. 46-47.

${ }^{12}$ Becky, dalam Miftah Thoha, Perspektif Perilaku Birokrasi, Cetakan ke-1, (Jakarta: Rajawali Pers, 1987), him. 165- 169 .
} 
membuat keputusan untuk kelompoknya. - Dalam beberapa hal, tindakannya mempunyai legitimasi, kadangkala tidak. Cara pengambilan keputusan minoritas yang mempunyai legitimasi, misalnya bertindak sebagai panitia pelaksana. Panitia ini terdiri dari para anggota saja, dan membuat keputusan yang amat penting untuk kelompoknya. Adapun tindakan minoritas yang tidak mempunyai legitimasi dengan cara-cara yang sukarela. Misalnya dua-tiga orang bersetuju untuk melaksanakan serangkaian tindakan dan menawarkan kepada anggota kalau ada komentar, kritik, dan saran. Jika tidak ada jawaban, mereka akan meneruskan ke pertanyaan berikutnya. Cara semacam ini dinamakan "railroading." Anggota minoritas yang membuat keputusan ini mungkin terikat pada keputusan yang dibuatnya, akan tetapi anggota mayoritas barangkali tidak mau terikat. Dalam cara ini "railroading" ini, jika ada anggota yang ditanya akan tetapi jawabannya diam, maka dianggap setuju.

(6) Keputusan Dilakukan oleh Mayoritas. Mekanisme pengambilam keputusan macam ini adalah dengan membagi kelompok atas dua bagian, yakni mereka yang "menang" dan mereka yang "kalah". Minoritas yang tidak ikut dalam pemungutan suara sama sekali tidak memberikan sahamnya dalam mempengaruhi keputusan yang diambilnya,

(7) Keputusan Dengan Konsensus. Keputusan yang diambil dengan cara konsensus merupakan sebuah keputusan yang kualitasnya paling tinggi, dan karenanya merupakan cara pengambilan keputusan yang paling efektif. Ada beberapa cara mencapai konsensus dalam pengambilan keputusan, antara lain:

(1) Menghindari argumentasi yang memaksakan pendapatnya sendiri;

(2) Menghindari usaha yang mudah mengubah pendapat hanya karena ingin mencapai persetujuan dan tidak menginginkan konflik;

(3) Menghindari prosedur mengurangi konflik, misalnya melalui pemungutan suara, "hom pimpah" (tossing a coin), tawar menawar (bargaining), dan yang sejenisnya;

(4) Mengenali pendapat yang berbeda;

(5) Janganlah mempunyai dugaan terlebih dahulu bahwa seseorang harus menang dan lainnya harus kalah ketika diskusi mencapai kemacetan (stalemate), sebaliknya hendaknya dicari alternatif lain yang bisa diterima oleh anggota kelompok;

(6) Mendiskusikan asumsi-asumsi yang disepakati, mendengarkan secara aktif dan seksama anggota lainnya, dan mendorong partisipasi semua anggota.

Secara yuridis, dewasa ini berbagai usaha yang melibatkan partisipasi masyarakat, misalnya di bidang lingkungan pengaturannya dapat ditemukan dalam berbagai peraturan perundang-undangan, antara lain:13

(1) Pasal 37 UU Nomor 5 Tahun 1990 Tentang Konsevasi Sumber Alam Hayati dan Ekosistemnya:

13Zairin Harahap, op. cit., hlm. 61 -66. 
(a) Peran serta rakyat dalam konservasi sumber daya alam hayati dan ekosistemnya diarahkan dan digerakkan oleh pemerintah melalui beberapa kegiatan yang berdaya guna dan berhasil guna.

(b) Dalam pengembangan peran serta rakyat sebagaimana dimaksud dalam ayat (1), pemerintah menumbuhkan dan meningkatkan sadar konservasi sumber daya alam hayati dan ekosistemnya di kalangan rakyat melalui pendidikan dan penyuluhan.

(c) Ketentuan lebih lanjut sebagaimana dimaksud dalam ayat (1) dan ayat (2) diatur dengan peraturan pemerintah. Penjelasan ayat (1) mengatakan bahwa peran serta rakyat dapat berupa perorangan dan kelompok baik yang terorganisasi maupun yang tidak. Agar rakyat dapat berperan secara aktif dalam kegiatan konservasi sumber daya alam hayati dan ekosistemnya, maka melalui kegiatan penyuluhan pemerintah perlu mengarahkan dan menggerakkan rakyat dengan mengikutsertakan kelompokkelompok masyarakat.

(2) Pasal 18 ayat (2) UU Nomor 5 Tahun 1992 Tentang Benda Cagar Budaya, yang menyebutkan "Masyarakat, kelompok, atau perorangan berperan serta dalam pengelolaan benda cagar budaya dan status".

(3) UU Nomor 24 Tahun 1992 Tentang Penataan Ruang: (a) Pasal 4 ayat (2) huruf b: "Setiap orang berhak berperan serta dalam penyusunan rencana tat ruang, pemanfaatan ruang, dan pengendalian pemanfaatan ruang". Dalam penjelasannya antara lain disebutkan bahwa "Hak setiap orang dalam penataan ruang dapat diwujudkan dalam bentuk bahwa setiap orang dapat mengajukan usul, memberi saran atau mengajukan keberatan kepada pemerintah dalam rangka penataan ruang." (b) Pasal 5 ayat (1) "Setiap orang berkewajiban berperan serta dalam memelihara "kualitas ruang". Dalam penjelasannya antara lain disebutkan bahwa "Kewajiban dalam memelihara kualitas ruang merupakan pencerminan rasa tanggung jawab sosial setiap orang terhadap pemanfaatan ruang".

(4) UU. Nomor 23 Tahun 1997 Tentang Pengelolaan Lingkungan Hidup:

(a) Pasal 5 ayat (3) "Setiap orang mempunyai hak untuk berperan dalam rangka pengelolaan lingkungan hidup sesuai dengan peraturan perundang-undangan yang berlaku". Dalam penjelasannya menyebutkan bahwa "peran sebagaimana dimaksud dalam pasal ini meliputi peran dalam proses pengambilan keputusan, baik dengan cara mengajukan keberatan, maupun dengar pendapat atau dengan cara lain yang ditentukan dalam peraturan perundang-undangan. Peran tersebut dilakukan antara lain dalam proses penilaian analisis mengenai dampak lingkungan hidup atau perumusan kebijaksanaan lingkungan hidup. Pelaksanaannya didasarkan pada prinsip keterbukaan. Dengan keterbukaan dimungkinkan masyarakat ikut memikirkan dan memberikan pandangan serta pertimbangan dalam pengambilan keputusan di 
bidang pengelolaan lingkungan hidup".

(b) Pasal 7:

(1) Masyarakat mempunyai kesempatan yang sama dan seluasluasnya untuk berperan dalam pengelolaan lingkungan hidup;

(2) Pelaksanaan ketentuan pada ayat (1) di atas, dilakukan dengan cara:

a. Meningkatkan kemandirian, keberdayaan masyarakat, dan kemitraan;

b. Menumbuhkembangkan kemampuan dan kepeloporan masyarakat;

c. Menumbuhkan ketanggapsegeraan masyarakat untuk melaksanakan pengawasan sosial;

d. Memberikan saran pendapat;

e. Menyampaikan informasi dan atau menyampaikan laporan.

(5) UU Nomor 41 Tahun 1999 Tentang Kehutanan:

(a) Pasal 60 ayat (2) Masyarakat dan atau perorangan berperan serta dalam pengawasan kehutanan.

(b) Pasal 69 ayat (1) Masyarakàt berkewajiban untuk ikut serta memelihara dan menjaga kawasan hutan dari gangguan dan perusakan. Dalam penjelasannya disebutkan bahwa "Yang dimaksud dengan memelihara dan menjaga adalah mencegah dan menanggulangi terjadinya pencurian, kebakaran hutan, gangguan ternak, perambahan penduduk, dan lain sebagainya".

(c) Pasal 70:
(1) Masyarakat turut berperan serta dalam pembangunan di bidang kehutanan;

(2) Pemerintah wajib mendorong peran serta masyarakat melalui berbagai kegiatan di bidang kehutanan yang berdaya guna dan berhasil guna;

(3) Dalam rangka meningkatkan peran serta masyarakat pemerintah dan pemerintah daerah dapat dibantu oleh forum pemerhati kehutanan. Dalam penjelasannya disebutkan bahwa "Forum pemerhati kehutanan merupakan mitra pemerintah dan pemerintah daerah untuk meningkatkan peran serta masyarakat dalam pengurusan hutan dan berfungsi merumuskan dan mengelola persepsi, aspirasi, dan inovasi masyarakat sebagai masukan bagi pemerintah dalam rangka perumusan kebijakan. Keanggotaan forum antara lain terdiri dari organisasi profesi kehutanan, lembaga swadaya masyarakat yang bergerak di bidang kehutanan, tokoh-tokoh masyarakat, serta pemerhati kehutanan.

(6) Peraturan Pemerintah Nomor 27 Tahun 1999 Tentang Analisis Mengenai Dampak Lingkungan:

(a) Pasal 33:

(1) Setiap usaha dan atau kegiatan sebagaimana dimaksud dalam pasal 3 ayat (2) wajib diumumkan terlebih dahulu kepada masyarakat sebelum pemrakarsa menyusun 
analisis mengenai dampak lingkungan.

(2) Pengumuman sebagaimana dimaksud pada ayat (1) dilakukan oleh instansi yang bertanggung jawab dan pemrakarsa. Dalam penjelasannya disebutkan bahwa "Pengumuman oleh instansi yang bertanggung jawab dapat dilakukan msialnya; melalui media cetak dan atau media elektronik. Sedangkan pengumuman oleh pemrakarsa dapat dilakukan dengan memasang papan pengumuman di lokasi akan diselenggarakannya usaha dan atau kegiatan".

(3) Dalam jangka waktu 39 (tiga puluh) hari kerja sejak diumumkannya rencana usaha dan atau kegiatan sebagaimana dimaksud pada ayat (1) warga masyarakat yang berkepentingan berhak mengajukan saran, pendapat, dan tanggapan tentang akan dilaksanakannya rencana usaha dan atau kegiatan;

(4) Saran, pendapat, dan tanggapan sebagaimana dimaksud pada ayat (3) diajukan secara tertulis kepada instansi yang bertanggung jawab;

(5) Saran, pendapat, dan tanggapan sebagaimana dimaksud pada ayat (3) wajib dipertimbangkan dan dikaji dalam analisis mengenai dampak lingkungan hidup;
(6) Tata cara dan bentuk pengumuman sebagaimana dimaksud pada ayat (1), serta tata cara penyampaian saran, pendapat, dan tanggapan sebagaimana dimaksud pada ayat (3) ditetapkan oleh kepala instansi yang ditugasi mengendalikan dampak lingkungan.

(b) Pasal 34:

(1) Warga masyarakat yang berkepentingan wajib dilibatkan dalam proses penyusunan kerangka acuan, penilain kerangka acuan, analisis dampak lingkungan hidup, rencana pengelolaan lingkungan hidup, dan rencana pemantauan lingkungan hidup;

(2) Bentuk dan tata cara keterlibatan warga masyarakat sebagaimana dimaksud pada ayat (1) ditetapkan oleh kepala instansi yang ditugasi mengendalikan dampak lingkungan.

\section{Simpulan}

Pada bagian ini, dengan mengutip pendapat Miftah Toha dalam bukunya "Bebepara Aspek Kebijakan Birokrasi" akan diuraikan keuntungan yang diperoleh dari adanya partisipasi masyarakat antara lain: ${ }^{14}$

(1) Keuntungan dari adanya partisipasi masyarakat dapat memecahkan persoalan yang tidak diperkirakan sebelumnya.

(2) Dengan partisipasi masyarakat, planner

14Miftah Thoha, "Beberapa Aspek Kebijakan Birokrasi" , op. cit., hlm. 19-20. 
dan para birokrat pada umumnya akan mendapatkan informasi setepat-tepatnya bagi mereka.

(3) Rakyat akan sangat menerima perubahan yang diadakan jika mereka diajak berperan serta di dalam merancang untuk menghasilkan perubahan itu. Proses yang harus dimulai dari saat merancang, mengkonstruksi, melaksanakan, dan sampai pada saat mengevaluasinya.

(4) Beberapa studi telah membuktikan bahwa dengan partisipasi akan banyak menghemat biaya, kalau di bidang pembangunan misalnya, dengan cara memoblisasikan tenaga kerja tak terpakai (unused labour) dan sumber-sumber daya lokal lainnya.

(5) Telah banyak diketahui bahwa keterlibatan rakyat itu memberikan manfaat yang besar sekali dalam merampungkan suatu proyek. Sekali rakyat menerima suatu proyek seperti yang diharapkan, maka mereka berkeinginan menjaga proyek itu mulai dalam pelaksanaan sampai tercapainya. Mereka mengetahui bahwa dengan proyek itu akan memetik buahnya nanti.

(6) Proses monitoring merupakan kegiatan yang memerlukan datang sindiri ke lapangan itu justru akan lebih bermanfaat dan efisien jika orang-orang lokal dilibatkan. Monitoring yang baik jika menekankan pada sistem di mana rakyat bisa mengawasi dan memonitor dirinya sendiri.

(7) Partisipasi merupakan proses pendidikan. Dengan partisipasi rakyat dididk untuk merasakan ikut memiliki, menjaga, dan mengendalikan setiap program yang

\section{dibuat bersama.}

Adapun yang menjadi hambatan dari partisipasi masyarakat adalah hambatan internal yang berupa hambatan sosio-kultural, dan hambatan eksternal yang paling dominan ialah hambatan dari birokrasi pemerintah: ${ }^{15}$ Hambatan internal, merupakan keengganan sebagian besar rakyat untuk terlibat ikut serta dalam suatu kegiatan. Keengganan ini dikarenakan sosio-kultural mereka belum memungkinkan mereka bisa aktif menyuarakan, menyampaikan dan mengutarakan keinginankeinginan mereka. Sikap semacam ini lebih banyak mendominasi rakyat pedesaan yang lebih dikenal dengan budaya diam. Mereka telah puas dengan apa yang ada di sekitar lingkungannya, dan mereka tidak mempunyai keinginan untuk sama sekali mengubah cara hidupnya. Dengan memahami keadaan sosiokultural rakyat pedesaan seperti ini, maka jelaslah mereka kurang dan bahkan tidak tertarik akan partisipasi.

Selain itu, keengganan rakyat untuk berpartisipasi itu disebabkan pula karena sikap dan perilaku para birokrat yang lebih banyak membuat jarak dengan rakyat. Di mata rakyat birokrat pemerintah merupakan seonggok manusia yang mempunyai keistimewaan kedudukan, wewenang, dan cara bertindak yang berbeda dengan mereka. Seonggok manusia yang sangat menakutkan, suka merampas haknya, meminta pelayanan rakyat, dan meminta sumbangan cuma-cuma. Sikap semacam ini terkesan lama bagi rakyat desa yang memang masih sederhana dan lugas cara berpikir dan bertindaknya. Inilah yang membuat partisipași ini merupakan suatu

${ }^{15} / \mathrm{bid}$, hlm. $21-24$. 
hambatan bagi mereka dan birokrat. Faktor lain yang termasuk hambatan internal ini ialah tingkat kesadaran rakyat yang amat rendah untuk berpartisipasi.

Sedangkan hambatan pokok di bidang eksternal dapat dialamatkan kepada birokrasi sendiri. Hambatan ini merupakan hambatan yang melekat pada badan politik dan rutinitas mesin birokrasi. Hampir seluruh badan-badan pengelola pembangunan pemerintah (Government-administered development agencies) telah ada sebelum partisipasi menjadi bagian dari falsafah pembangunan sekarang ini. Para birokrat pada umumnya merancang segala aspek pembangunan yang menjadi salah satu tugas utama pemerintah itu secara terpusat (centralized). Pendekatan pelayanan publik yang didasarkan atas kelenturan dan ketanggapan (flexibility and responsiveness) terhadap kebutuhan-kebutuhan di bidangnya sama sekali tidak diperhatikan. Oleh karenanya, semua program instansi pemerintah banyak yang kekurangan orientasi pembangunan. Partisipasi dan pikiran-pikiran inovatif merupakan slogan nyanyian belaka. Para pengamat perilaku birokrasi pemerintah hampir semua setuju bahwa pembaharuan yang mencoba keluar dari tatanan hierarchie yang ada selalu dihindari oleh para birokrat.

Para birokrat percaya serius bahwa mereka sendiri mempunyai jawaban-jawaban untuk mengatasi segala persoalan kemiskinan, dan oleh karenanya mereka sendiri satu-satunya yang berwenang dan mengetahui seluk-beluk kemiskinan itu. menurut kerangka pengetahuan mereka hanya kepada orang-orang yang mampu berperan saja yang seharusnya bisa berpartisipasi, sedangkan sisanya harus mau menerima sistem pelayanan yang ditetapkan.o

\section{Daftar Pustaka}

Atmosudirdjo, Prajudi, Beberapa Pandangan Umum Tentang Pengambilan Keputusan, Tanpa Penerbit, Jakarta, 1976.

Harahap, Zairin, Diktat Mata Kuliah Hukum Administrasi Negara Lanjut, F. H. - Ull, Yogyakarta, 2001.

Kumartono, Wahyudi, Etika Administrasi Negara, Cetakan ke-1, Rajawali Press, Jakarta, 1992.

Thoha, Miftah, Perspektif Perilaku Birokrasi, Cetakan ke-1, Rajawali Pers, Jakarta, 1987.

, Beberapa Aspek Kebijakan Birokrasi, Cetakan ke-1, Widya Mandala, Yogyakarta, 1991.

Wirosardjono, Soetjipto, Dialog Dengan Kekuasaan, Cetakan ke-1, Mizan, Bandung, 1995.

20000 